\title{
Core Knowledge and Specialized Skills in Academic Libraries
}

\section{Laura Saunders}

Academic libraries are challenged to keep pace with major changes and trends in the fields of library and information science and higher education generally. Through a nationwide survey of information professionals and LIS faculty, this study explores the knowledge, skills, and abilities (KSAs) currently in demand for academic librarians and compares them to those expected of information professionals in other areas of the field. The results show a strong emphasis on interpersonal and communication skills as well as certain domain knowledge. The results also suggest some significant differences between expectations for academic librarians compared to other information professionals.

Academic libraries are challenged to keep pace with major changes and trends in the fields of library and information science and higher education generally. Changes in technology are impacting patron expectations of when, where, and how resources and services are accessed, including access to instruction and degree programs. Shifts in pedagogy are driving a need for tools and the physical and virtual spaces to support active and collaborative learning. Vast increases in information and data sources and changes in scholarly communications are impacting how scholars find and use information and require people to organize, manage, and provide access to those sources. Information and related literacies such as news literacy, digital literacy, and so on continue to be recognized as essential skills for college students, offering opportunities for librarians to support the educational mission of the college by providing instructional support in these areas. At the same time, stakeholders ranging from accreditation organizations to the federal government to parents and students are increasing their scrutiny of higher education and demanding evidence that these institutions are achieving their missions and goals. In turn, campuses are looking to departments, including libraries, to gather and analyze data to demonstrate their contribution to these missions and goals and their value to the campus community.

These trends have implications for the knowledge, skills, and abilities (KSAs) that current and emerging information professionals need to succeed in the academic library workplace and, in turn, will impact curricula as iSchools strive to prepare emerging professionals to meet these needs. Some of the trend areas build and expand on the traditional library functions of collecting and organizing information and facilitating access through reference and instruction

\footnotetext{
*Laura Saunders is Associate Professor in the School of Library and Information Science at Simmons University; email: laura.saunders@simmons.edu. @2020 Laura Saunders, Attribution-NonCommercial (http://creativecommons.org/licenses/by-nc/4.0/) CC BY-NC.
} 
services, while others suggest the need for entirely new skill sets. Further, academic librarianship encompasses many roles and responsibilities, and the specific knowledge and skill sets needed could vary depending on job functions. Through a nationwide survey of information professionals and LIS faculty, this study explores the knowledge, skills, and abilities (KSAs) currently in demand for academic librarians. Specifically, this study examines the following questions: Which KSAs are specific to academic librarianship? How do those KSAs compare to those expected of information professionals in other areas of the field? What KSAs are considered core for academic librarians, regardless of their specific position or job functions? The results of this study will be of interest to academic library directors, campus administrators, and others concerned with trends in academic libraries, as well as LIS students interested in academic library careers. The results of this study could also be of interest to LIS faculty as they review and develop curricula to prepare emerging academic library professionals.

\section{Literature Review}

Professional associations often codify the knowledge and skills related to their professions, and librarianship is no different. The American Library Association (ALA) provides a statement on the Core Competences of Librarianship, which lays out specific skills, qualities, and areas of knowledge organized around 8 main areas of: foundations of the profession; information resources; organization of recorded knowledge and information; technological knowledge and skills; reference and user services; research; continuing education and lifelong learning; and administration and management. ${ }^{1}$ As the accrediting body for master's programs in library and information science, ALA also provides standards for accreditation related to curriculum, which state that all graduates from such programs should be able to "assume a leadership role in providing services and collections appropriate for the communities that are served," be familiar with "findings of basic and applied research from relevant fields," integrate "technology and the theories that underpin its design, application, and use," and respond "to the needs of a diverse and global society, including the needs of underserved groups." 2 These standards and competencies are meant to apply across the field of LIS, while the Association for College and Research Libraries, a division of ALA, publishes additional standards and guidelines specific to academic librarianship. These include standards of proficiencies for assessment librarians, which acknowledge the increased attention to accountability and need to demonstrate evidence of achievement. Assessment librarians are expected to understand research design and assessment methods and strategies and be able to collect and analyze data. ${ }^{3}$ Similarly, the Roles and Strengths of Teaching Librarians underscores the centrality of information literacy and library instruction within academic libraries and defines core areas for instruction librarians including pedagogy, instructional design, advocacy, and assessment. ${ }^{4}$ Diversity Standards: Cultural Competency for Academic Librarians highlights the importance of cultural sensitivity and attention to underserved and marginalized groups in provision of services, ${ }^{5}$ while Standards for Distance Learning outlines skills and knowledge areas necessary to providing equitable distance services for remote and online students. ${ }^{6}$

While these standards and guidelines are useful baselines, they are generally written at a broad level and are only updated irregularly. ALA's Core Competencies, for example, are more than a decade old; as such, they might not reflect the most current and specific needs of the field. These standards can be supplemented by other sources. For example, trend reports identify current issues in the field, many of which will have implications in terms of knowledge 
and skills needed to respond to those issues, while research studies analyze job postings and use interviews and focus groups to identify skills and qualifications currently of interest to hiring managers in academic libraries. For instance, every other year, ACRL publishes a list of the top ten trends impacting academic libraries. Issues related to data services, including research data management, data science, and research dataset acquisitions, appeared on both the 2016 and 2018 lists. ${ }^{7}$ An increase in data services in academic libraries could signal a need for new knowledge and skills. Indeed, several studies have analyzed job postings for data services positions. For example, Lisa Federer surveyed practitioners to develop a taxonomy of skills and expertise necessary for data librarians. She identified a range of skills clustered around the areas of data management, IT, evaluation and assessment, instruction, and outreach. ${ }^{8}$ Jingfeng Xia and Minglu Wang ${ }^{9}$ and Hsin-liang Chen and Yin Zhang ${ }^{10}$ analyzed job descriptions for data science librarians and likewise found an emphasis on skills related to data management and curation, quantitative and qualitative analysis, and statistics, as well as experience with teaching and training related to data.

Information literacy and instruction, as well as related areas such as assessment of student learning outcomes, continue to be major areas for academic libraries. ACRL's Top Trends for $2018^{11}$ included information literacy and fake news, while the $2016^{12}$ list identified applications of the Framework for Information Literacy for Higher Education ${ }^{13}$ and critical information literacy programs as well as learning outcomes assessment as major trends. These trends related to information literacy and instruction are supported by Ithaka S+R surveys, which found that more than 60 percent of resources are allocated to three key service areas, which are to enable academic success through supporting instruction, facilitating learning, and promoting information literacy; to facilitate information access by promoting discovery and usage of information sources across formats; and to provide study space. ${ }^{14}$ Further, the report suggests that, during the next few years, academic libraries expect to shift resources away from services focused on information access and collections as they concentrate more on enabling student learning. These results align with earlier studies in which library directors identified instruction services as their top priority and predicted the most growth in positions related to teaching and research support, specifically instruction, instructional design, information literacy, and faculty research support. ${ }^{15}$ Indeed, in each survey since Ithaka began these studies in 2010, more than 90 percent of academic library directors have rated the statement that "the library helps undergraduates develop research, critical analysis, and information literacy skills" as important, and it is the most highly rated function in terms of importance for baccalaureate, master, and doctoral institutions.

The emphasis on information literacy and library instruction in these surveys suggests the importance of pedagogy and instructional skills for academic librarians, a suggestion that is confirmed by several studies. One study of job ads found a steady increase over 40 years in reference services positions in academic libraries, including instruction as a core area of those jobs. ${ }^{16}$ Robert Detmering and Claudene Sproles found that nearly 98 percent of academic library reference jobs included responsibilities for information literacy and instruction. ${ }^{17}$ Russell Hall confirmed that academic library directors identify instruction as highly important, finding that more than a quarter of librarians with instructional responsibilities spend 50 percent or more of their time on instruction. ${ }^{18}$ Other studies have focused on the need for skills related to distance learning and designing and delivering online instruction. ${ }^{19}$

Of course, changes in technology have permeated all aspects of academic libraries, and a number of studies point to the importance of technical skills. In fact, Janie M. Mathews and 
Harold Pardue suggested "a significant intersection between the skill sets of librarians and the skill sets of IT professionals." ${ }^{20}$ Their review of job ads found that 72 percent included at least one IT skill set, with web development skills being among the most frequently listed. Technical skills related to project management, systems development, and systems applications were also popular. Another study estimated that nearly three-quarters of academic library job postings in South Africa called for advanced technical skills ranging from general computer skills to specific knowledge of ILS systems, metadata standards, and digital repository, content management, and open source publishing software ${ }^{21} \mathrm{~A}$ series of focus groups of Australian library professionals determined that technology qualifications for librarians are less about specific hardware and software skills and more about a mindset of being open to new technology and willing to engage in continual learning. ${ }^{22}$ Indeed, a series of focus groups in the United States indicated that, while librarians agreed that technology skills were among the most important for librarians, there was little agreement about which specific skills were most sought. ${ }^{23}$

Other studies have identified a wide range of additional skills and knowledge areas for academic librarians, including management and leadership abilities, ${ }^{24}$ cultural competencies and the ability to work with diverse communities, ${ }^{25}$ outreach and marketing ${ }^{26}$ development and fundraising, ${ }^{27}$ and copyright literacy. ${ }^{28}$ Acknowledging the increasing need of academic librarians to gather data to demonstrate value, a number of studies have underscored the importance of skills related to evaluation and assessment, ${ }^{29}$ including specific skills with tools such as SPSS and Stat..$^{30} \mathrm{~A}$ couple of studies have examined the extent to which academic libraries seek specific skills and qualifications such as knowledge of a foreign language ${ }^{31}$ or an advanced subject degree. ${ }^{32}$ Several studies have emphasized the importance of "soft skills" including interpersonal skills, writing and communication, and customer service skills, as well as adaptability, flexibility, and a willingness to learn. ${ }^{33}$ Indeed, many of the studies cited here signaled the importance of communication, interpersonal, and other "soft skills," even when those were not the focus of the study.

\section{Procedures}

This study was initially undertaken as part of a curriculum review at an ALA-accredited Master's of Library and Information Science program. Faculty and administrators in this program were reviewing the core curriculum and defining various paths to specialization within the broader curriculum. To determine how well the curriculum was meeting the perceived needs of the field, the faculty decided to conduct a survey of current practitioners who are actual and potential employers of program graduates, as well as LIS faculty, on which knowledge, skills, and abilities are considered core for information professionals and which are specialized. Thus, the focus of the initial study was to look broadly across all information settings and job functions. A large sample was necessary to obtain this broad view of the field. A survey was the most appropriate data collection method for this study because it allows for wide distribution to gather a greater number and variety of responses compared to other methods like focus groups or interviews. The larger sample ensured greater representation from the field and, thus a better baseline of consensus on which KSAs are core to the field.

The survey was developed by the researcher and piloted with the program faculty. After final revisions, the survey was distributed in March of 2017 to the total available list of the program's alumni, which numbered more than 4,000 people, as well as all internship and 
practicum supervisors, and all adjunct faculty. A link to the survey was also sent to several area listservs including local chapters of ASIS\&T, SAA, and SLA, the state library network, and a listserv of state public library directors. Subsequently, the researcher and the Dean of the iSchool shared the executive summary of the initial study with colleagues, and several other iSchools expressed interest in replicating the survey. Between April 2017 and September of 2018, four additional schools administered the survey to their respective populations. Each school chose their own distribution method and population for the study. Some directly emailed alumni and faculty, some provided a link in an alumni newsletter, and others sent the link through listservs.

The survey consisted of a list of 53 skills, aptitudes, and knowledge areas broken down into five categories: general, communication, user services, management, and technology (see appendix A for full survey). The list of skills was compiled from LIS literature, professional competency statements, and job postings. The purpose of the survey was to discover not just which skills and knowledge areas are considered important, but which are core to the field, meaning that every graduate of an ALA-accredited program should have some grounding in the area. Thus, respondents were asked to rate each of the KSAs on the following scale: Core (ALL MSLIS graduates should have a strong foundation regardless of area of concentration/career path); Very Important (most professionals will need to know/be able to do this); Important (many professionals will need to be familiar with this skill/content); Specialized (only professionals in specialized positions are likely to need this skill/knowledge); and Not Important. The survey concluded with demographic questions, and an open-ended question asking respondents if there were any skills omitted from the original list that should have been included.

The survey resulted in more than 2,400 responses from all five distributions of the survey. This article reports the findings from the academic librarians who participated in the survey, with comparison to the total population. Specifically, this report focuses on the following questions:

- Which knowledge, skills, and abilities are considered core for academic librarians? Which KSAs should all emerging professionals interested in an academic library career have firm grounding in, regardless of their particular job function or area of specialization?

- Which KSAs might be relevant only to practitioners in specialized academic library positions?

- How do the KSAs considered core by academic librarians compare to those identified as core from the larger survey population?

- How do the KSAs considered core by academic librarians align with current trends in the field?

\section{Limitations}

Surveys always run the risk of responder bias. It is possible that people who chose to respond to the survey share characteristics that differ from those who did not respond and that those differences skewed the survey outcomes. In particular, although the originating institution posted the survey to listservs and distributed it to area employers, including internship and field work supervisors who might not be alums of the program, the majority of respondents to this survey are primarily alumni and faculty of five iSchools in the United States. It is possible that these respondents have more traditional approaches to LIS and might not be reflective of 
the wider field. Indeed, the results indicate that the survey does not include many respondents without an MSLIS and thus does not represent the growing population of non-MLS degree holders now working in the field. Finally, the vast majority of respondents were from public and academic libraries, indicating that the survey results might not reflect the preferred skills and qualifications of information professionals working in less traditional settings. Thus, care must be taken in generalizing the results of this survey too broadly.

\section{Findings}

In total, 830 academic librarians responded to the survey, representing 34 percent of all survey respondents. Ninety-four percent of the academic library respondents have an MSLIS degree. These respondents held a variety of positions within academic libraries, with the largest percentage identifying as staff librarians (37\%) followed by department managers $(20 \%)$ and library directors/deans (19\%). The next largest position category was "other" $(12 \%)$. This category included some MSLIS students and paraprofessionals and some retirees, but the bulk of the write-in responses were subject/liaison librarians and librarians with faculty status, either tenured or on tenure track. Figure 1 illustrates the breakdown of respondents by position.

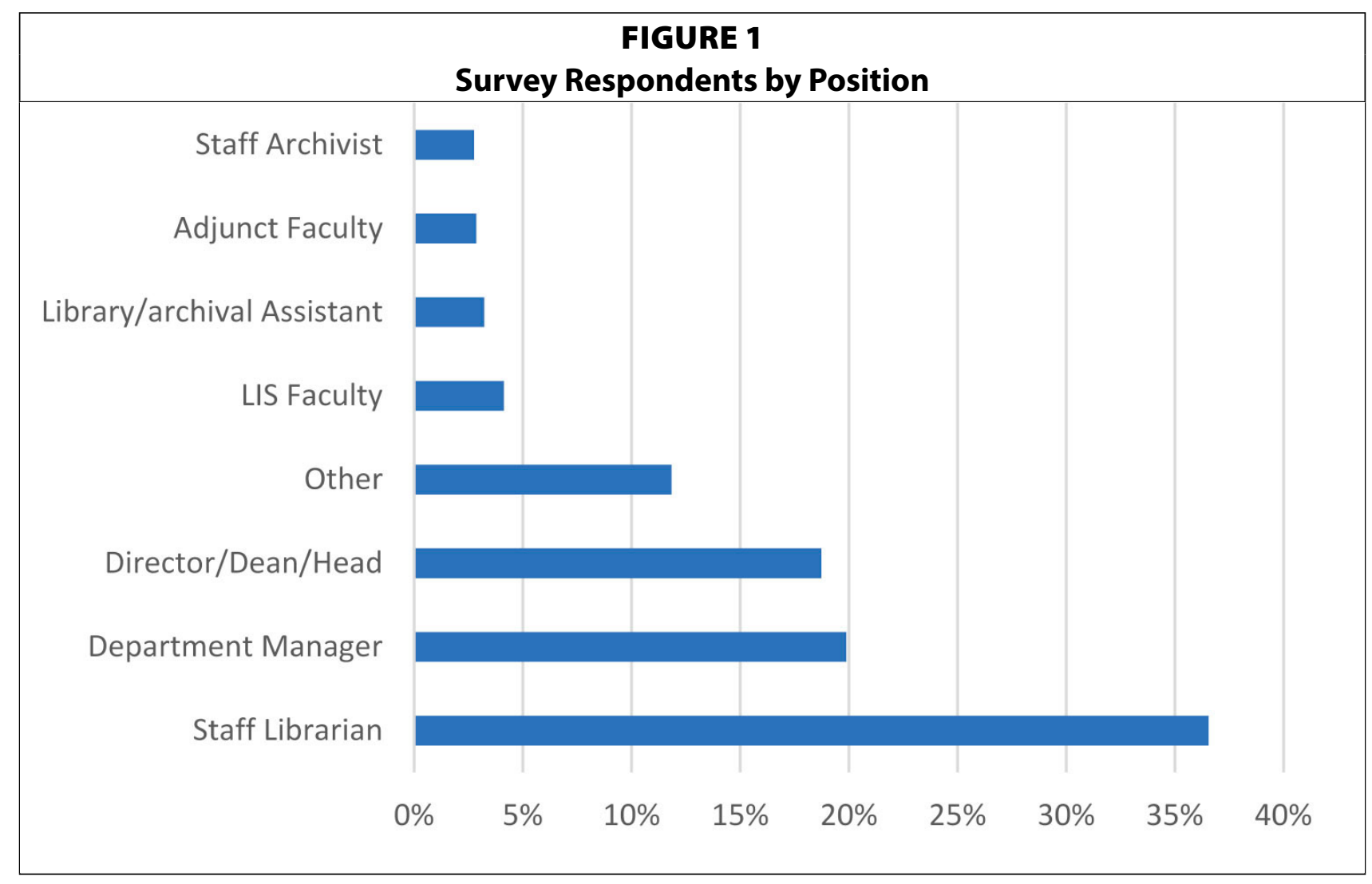

Out of 53 skills and knowledge areas, 10 were ranked as core by 50 percent or more of academic librarians: knowledge of professional ethics; evaluating and selecting information sources; cultural competence; reflective practice grounded in diversity and inclusion; interpersonal communication; writing; customer service; search skills; interacting with diverse communities; and teamwork. Figure 2 shows the percentage of academic librarians who ranked each of these skills as core. 

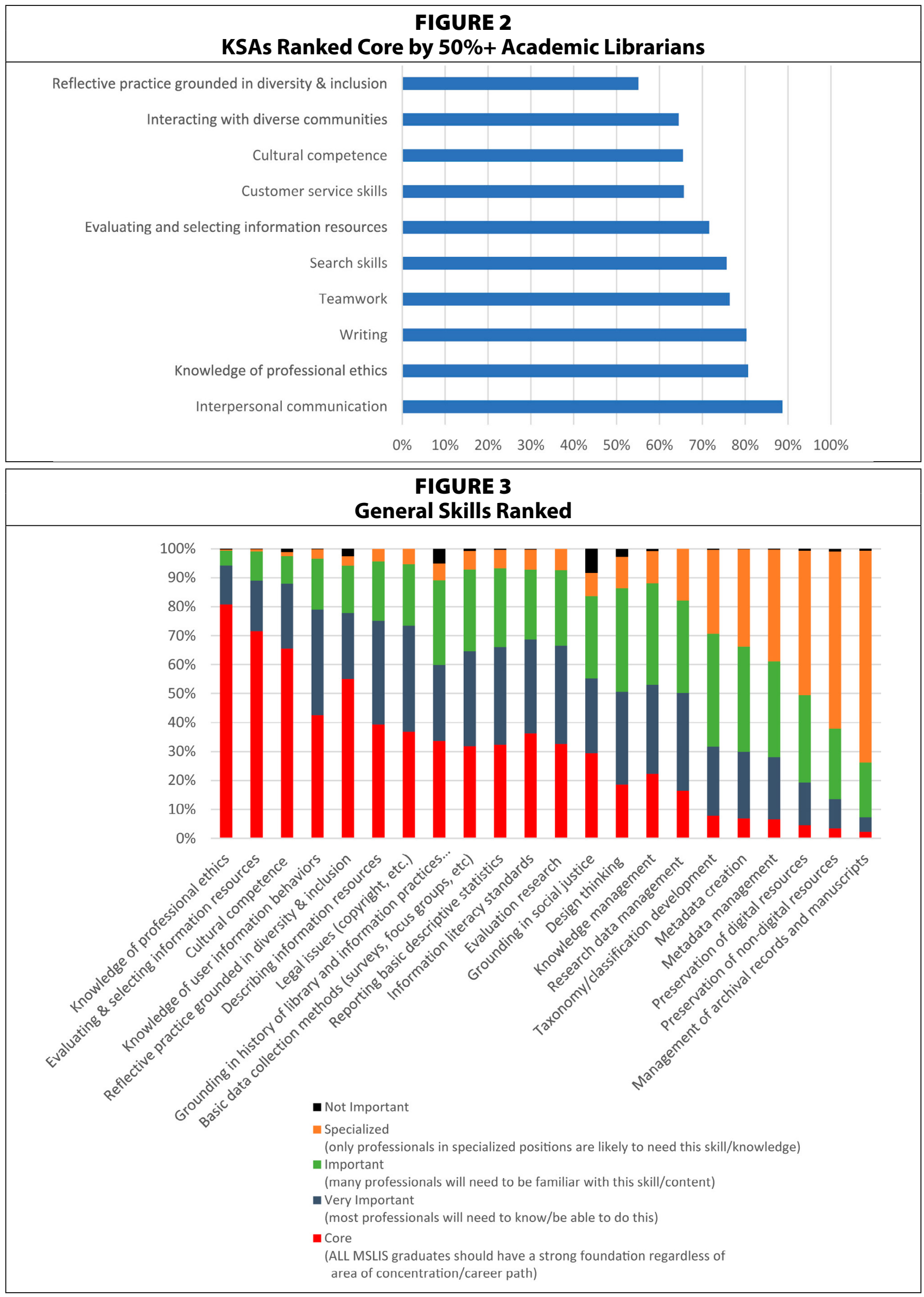

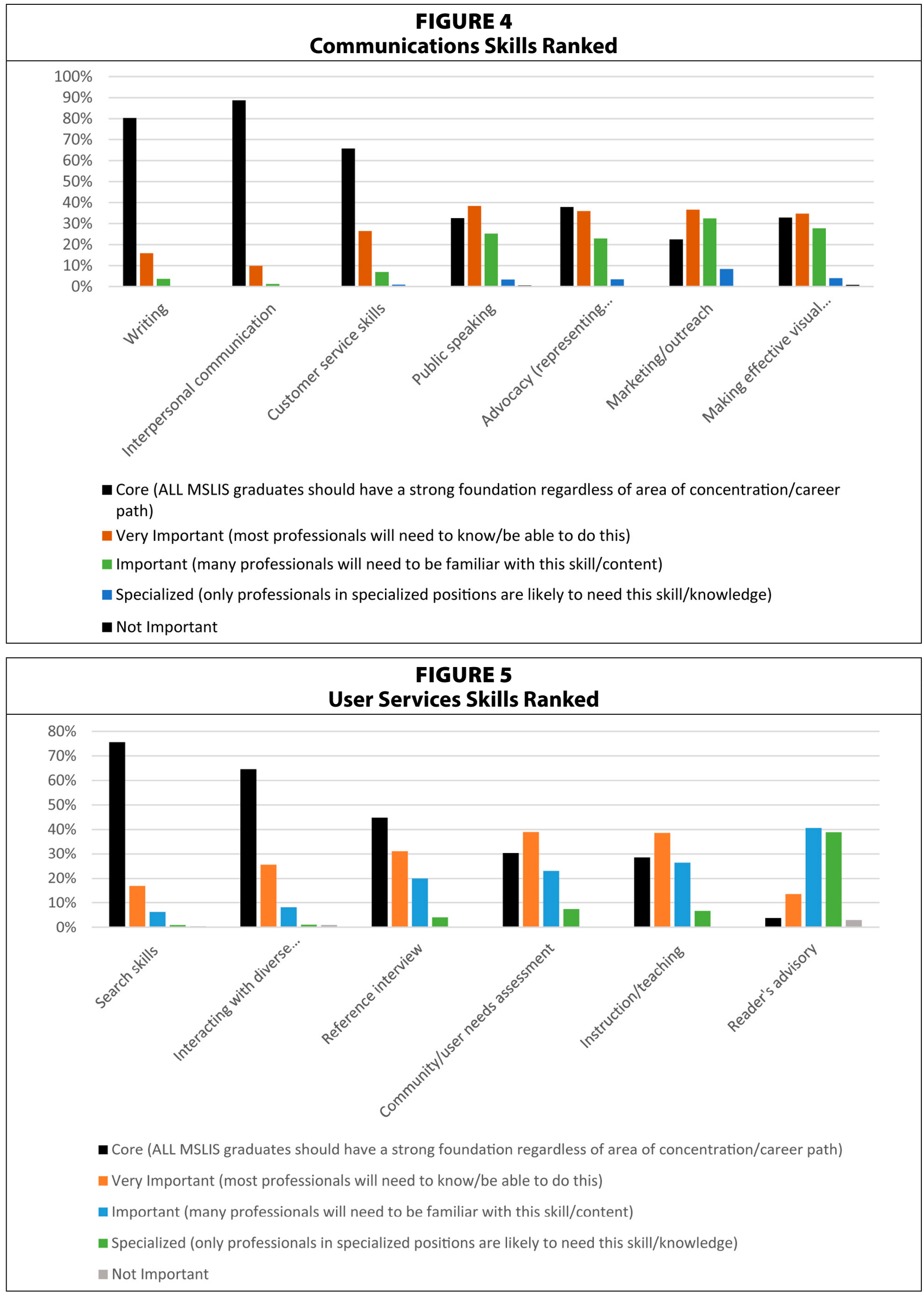


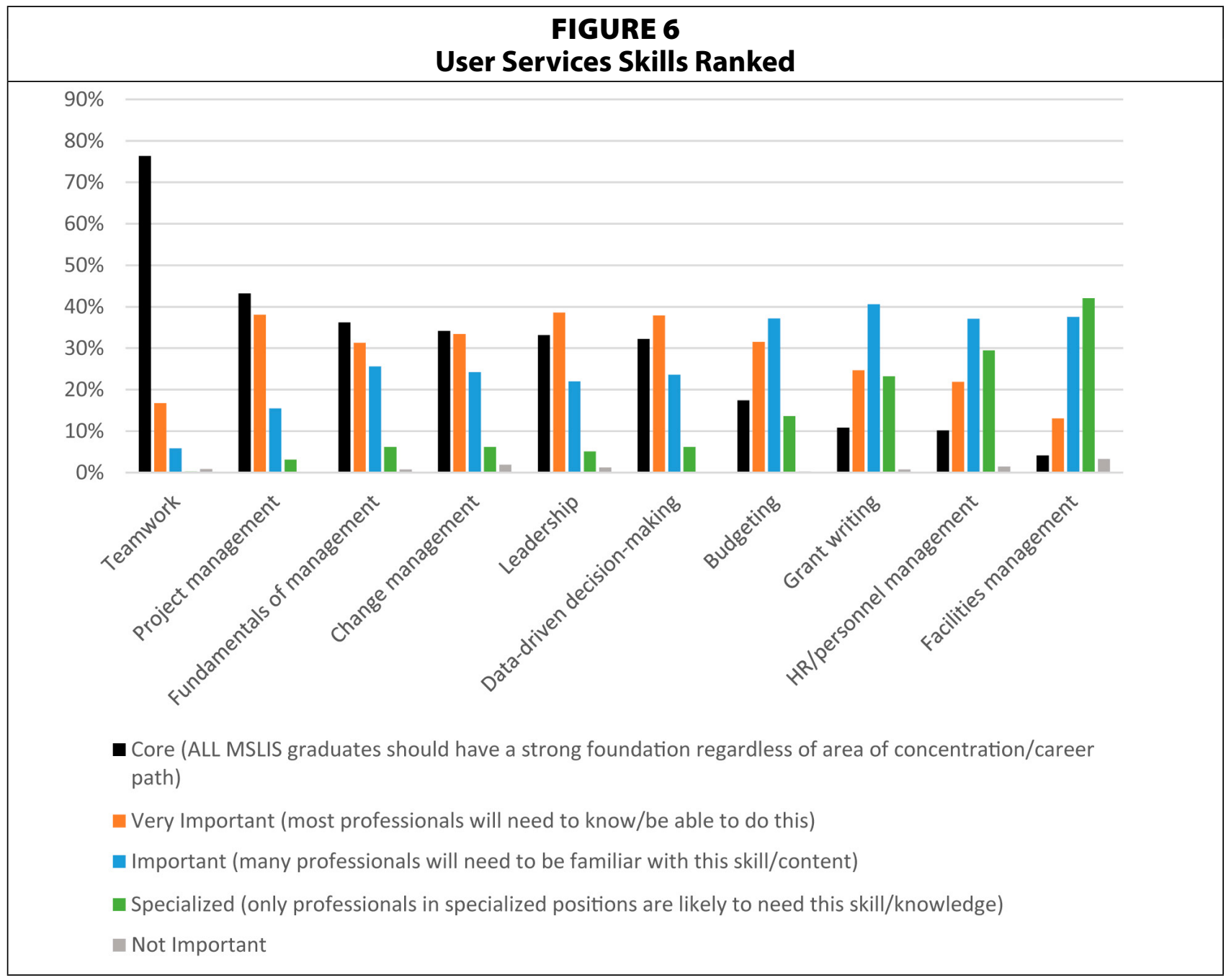

Skills not ranked as core were not necessarily considered unimportant or irrelevant. Many of the remaining 53 KSAs were ranked as very important or important, indicating that most academic librarians would need some familiarity with those skills and concepts, but they are not considered a necessary grounding for all academic librarians across positions. In fact, none of the 53 KSAs were ranked as "not important" by more than a handful of people. Further, only four KSAs of 53 were identified as specialized by 50 percent or more of participants, meaning those participants believe that only professionals in specialized positions are likely to need those skills or that knowledge. Those four areas included preservation of digital sources $(50 \%)$, preservation of nondigital sources $(61 \%)$, management of archival records and manuscripts (73\%), and managing network systems (65\%). Figures 3-7 show the rankings of all $53 \mathrm{KSAs}$, broken down by the survey categories of General, Communications, User Services, Management, and Technology.

One aim of this study was to compare core KSAs as identified by academic librarians to those ranked core by all other information professionals. After eliminating the 830 academic librarians from the responses, there were 1,624 respondents representing public, special, school, and corporate libraries, various archives, and some nontraditional settings such as database vendors. Looking just at the nonacademic librarian responses, $11 \mathrm{KSAs}$ were ranked as core by 50 percent or more of participants. These included the 10 selected by the academic librarians, as well as reference interview skills, which were identified as core by 53 percent of 


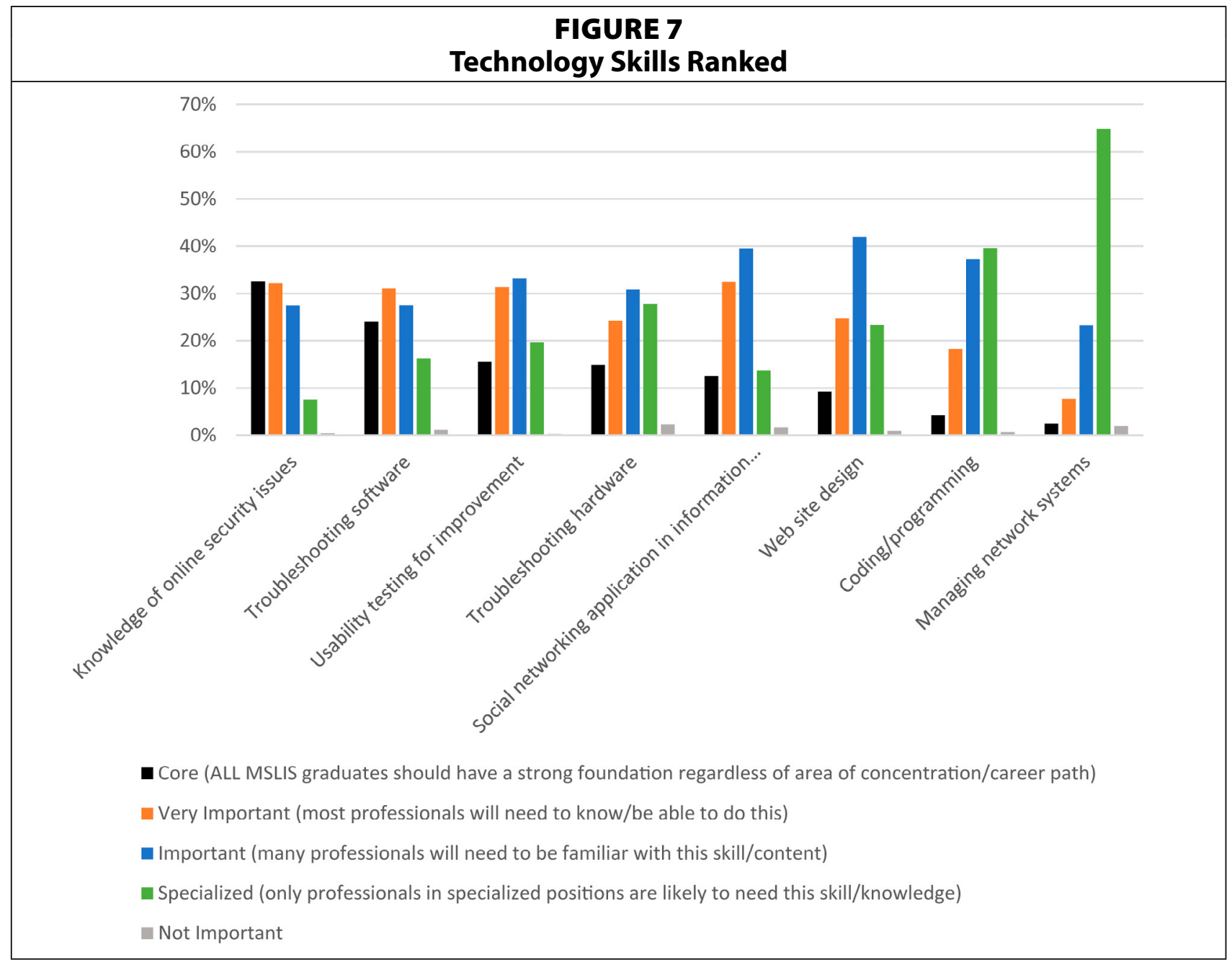

nonacademic librarian respondents. Only 45 percent of academic librarians ranked the reference interview as a core skill. While academic and nonacademic respondents ranked nearly all the same KSAs as core, they often did so at somewhat different rates. In fact, chi-square tests revealed that seven of the 11 skills showed a statistically significant difference in the rate at which each group ranked the KSAs as core. Table 1 shows the top 11 KSAs along with the percentage of academic and nonacademic librarians ranking each as core and whether there was a statistically significant difference in the ranking.

\begin{tabular}{|l|c|c|l|l|}
\hline \multicolumn{5}{|c|}{ TABLE 1 } \\
\hline KSA & $\begin{array}{l}\text { Percentage } \\
\text { of Academic } \\
\text { Librarians Ranking } \\
\text { KSA as Core }\end{array}$ & $\begin{array}{l}\text { Percentage of All } \\
\text { Other Information } \\
\text { Professionals } \\
\text { Ranking KSA as Core }\end{array}$ & p-value & Significance \\
\hline Interpersonal communication & $89 \%$ & $86 \%$ & .0256 & Significant \\
\hline $\begin{array}{l}\text { Knowledge of professional } \\
\text { ethics }\end{array}$ & $81 \%$ & $82 \%$ & .65 & NOT Significant \\
\hline Writing & $80 \%$ & $77 \%$ & .00085 & Significant \\
\hline Search skills & $76 \%$ & $81 \%$ & .0057 & Significant \\
\hline Teamwork & $76 \%$ & $76 \%$ & .7507 & NOT Significant \\
\hline
\end{tabular}




\begin{tabular}{|l|c|c|l|l|}
\hline \multicolumn{5}{|c|}{ TABLE 1 } \\
\hline KSA & $\begin{array}{l}\text { Percentage } \\
\text { of Academic } \\
\text { Librarians Ranking } \\
\text { KSA as Core }\end{array}$ & $\begin{array}{l}\text { Percentage of All } \\
\text { Other Information } \\
\text { Professionals } \\
\text { Ranking KSA as Core }\end{array}$ & p-value & Significance \\
\hline $\begin{array}{l}\text { Evaluating and selecting } \\
\text { information resources }\end{array}$ & $72 \%$ & $80 \%$ & .00005 & Significant \\
\hline Cultural competence & $66 \%$ & $65 \%$ & .703 & NOT Significant \\
\hline Customer service skills & $66 \%$ & $75 \%$ & .00001 & Significant \\
\hline $\begin{array}{l}\text { Interacting with diverse } \\
\text { communities }\end{array}$ & $65 \%$ & $60 \%$ & .0442 & Significant \\
\hline $\begin{array}{l}\text { Reflective practice grounded } \\
\text { in diversity \& inclusion }\end{array}$ & $55 \%$ & $51 \%$ & .053 & NOT Significant \\
\hline $\begin{array}{l}\text { Reference interview/question } \\
\text { negotiation }\end{array}$ & $45 \%$ & $53 \%$ & .00001 & Significant \\
\hline
\end{tabular}

Chi-square tests revealed there were statistically significant differences in how academic and nonacademic respondents rated many of the other skills, in addition to these 11 "core" KSAs. In fact, there were statistically significant differences in rankings for 24 of the remaining 42 skills. Table 2 lists those 42 skills along with the percentage of academic and nonacademic librarians ranking each as core, telling whether there was a statistically significant difference in the ranking.

\begin{tabular}{|c|c|c|c|c|}
\hline \multicolumn{5}{|c|}{$\begin{array}{c}\text { TABLE } 2 \\
\text { Significance in Skills Ranking between Academic and Non-Academic Respondents }\end{array}$} \\
\hline Skill & $\begin{array}{l}\text { Percentage } \\
\text { of Academic } \\
\text { Librarians } \\
\text { Ranking } \\
\text { KSA as Core }\end{array}$ & $\begin{array}{l}\text { Percentage of All } \\
\text { Other Information } \\
\text { Professionals } \\
\text { Ranking KSA as } \\
\text { Core }\end{array}$ & p-value & Significance \\
\hline \multicolumn{5}{|l|}{ General } \\
\hline $\begin{array}{l}\text { Describing information } \\
\text { resources }\end{array}$ & $39 \%$ & $49 \%$ & 0.000015 & Significant \\
\hline Legal issues (copyright, etc.) & $37 \%$ & $44 \%$ & 0.00151 & Significant \\
\hline Knowledge management & $22 \%$ & $27 \%$ & 0.0065 & Significant \\
\hline Research data management & $17 \%$ & $27 \%$ & 0 & Significant \\
\hline $\begin{array}{l}\text { Taxonomy/classification } \\
\text { development }\end{array}$ & $8 \%$ & $13 \%$ & 0.000089 & Significant \\
\hline Metadata creation & $7 \%$ & $10 \%$ & 0.01571 & Significant \\
\hline Metadata management & $7 \%$ & $10 \%$ & 0.0082 & Significant \\
\hline Preservation of digital resources & $5 \%$ & $9 \%$ & 0.0001 & Significant \\
\hline $\begin{array}{l}\text { Preservation of non-digital } \\
\text { resources }\end{array}$ & $3 \%$ & $7 \%$ & 0.0004 & Significant \\
\hline $\begin{array}{l}\text { Knowledge of user information } \\
\text { behaviors }\end{array}$ & $43 \%$ & $43 \%$ & 0.817 & NOT significant \\
\hline
\end{tabular}




\begin{tabular}{|c|c|c|c|c|}
\hline \multicolumn{5}{|c|}{$\begin{array}{c}\text { TABLE } 2 \\
\text { Significance in Skills Ranking between Academic and Non-Academic Respondents }\end{array}$} \\
\hline Skill & $\begin{array}{l}\text { Percentage } \\
\text { of Academic } \\
\text { Librarians } \\
\text { Ranking } \\
\text { KSA as Core }\end{array}$ & $\begin{array}{l}\text { Percentage of All } \\
\text { Other Information } \\
\text { Professionals } \\
\text { Ranking KSA as } \\
\text { Core }\end{array}$ & p-value & Significance \\
\hline Information literacy standards & $36 \%$ & $40 \%$ & 0.0875 & NOT significant \\
\hline $\begin{array}{l}\text { Grounding in history of library } \\
\text { and information practices and } \\
\text { professions }\end{array}$ & $34 \%$ & $30 \%$ & 0.0677 & NOT significant \\
\hline $\begin{array}{l}\text { Evaluation research (collecting } \\
\text { and analyzing data for purposes } \\
\text { of improvement) }\end{array}$ & $33 \%$ & $31 \%$ & 0.302 & NOT significant \\
\hline $\begin{array}{l}\text { Reporting basic descriptive } \\
\text { statistics }\end{array}$ & $32 \%$ & $30 \%$ & 0.2858 & NOT significant \\
\hline $\begin{array}{l}\text { Basic data collection methods } \\
\text { (surveys, focus groups, etc.) }\end{array}$ & $32 \%$ & $29 \%$ & 0.2327 & NOT significant \\
\hline Grounding in social justice & $29 \%$ & $30 \%$ & 0.8042 & NOT significant \\
\hline $\begin{array}{l}\text { Design thinking (approach or } \\
\text { strategy for innovation) }\end{array}$ & $19 \%$ & $21 \%$ & 0.1666 & NOT significant \\
\hline $\begin{array}{l}\text { Management of archival records } \\
\text { and manuscripts }\end{array}$ & $2 \%$ & $3 \%$ & 0.3566 & NOT significant \\
\hline \multicolumn{5}{|l|}{ Communication } \\
\hline $\begin{array}{l}\text { Advocacy (representing } \\
\text { organizational interests to } \\
\text { stakeholders) }\end{array}$ & $38 \%$ & $45 \%$ & 0.00042 & Significant \\
\hline Marketing/outreach & $23 \%$ & $32 \%$ & 0.000001 & Significant \\
\hline $\begin{array}{l}\text { Making effective visual } \\
\text { presentations }\end{array}$ & $33 \%$ & $32 \%$ & 0.6567 & NOT significant \\
\hline Public speaking & $33 \%$ & $31 \%$ & 0.4674 & NOT significant \\
\hline \multicolumn{5}{|l|}{ User Services } \\
\hline $\begin{array}{l}\text { Community/user needs } \\
\text { assessment }\end{array}$ & $30 \%$ & $38 \%$ & 0.0002 & Significant \\
\hline Reader's advisory & $4 \%$ & $23 \%$ & 0 & Significant \\
\hline $\begin{array}{l}\text { Instruction/teaching (f2f \& } \\
\text { online) }\end{array}$ & $28 \%$ & $31 \%$ & 0.27 & NOT significant \\
\hline \multicolumn{5}{|l|}{ Management } \\
\hline Fundamentals of management & $36 \%$ & $44 \%$ & 0.00018 & Significant \\
\hline Leadership & $33 \%$ & $43 \%$ & 0.000004 & Significant \\
\hline Budgeting & $17 \%$ & $31 \%$ & 0 & Significant \\
\hline Grant writing & $11 \%$ & $18 \%$ & 0.000003 & Significant \\
\hline HR/personnel management & $10 \%$ & $15 \%$ & 0.00047 & Significant \\
\hline Facilities management & $4 \%$ & $11 \%$ & 0 & Significant \\
\hline
\end{tabular}




\begin{tabular}{|l|c|c|c|c|}
\hline \multicolumn{5}{|c|}{ TABLE 2 } \\
\hline & $\begin{array}{l}\text { Percentage } \\
\text { of Academic } \\
\text { Librarians } \\
\text { Ranking } \\
\text { KSA as Core }\end{array}$ & $\begin{array}{l}\text { Percentage of All } \\
\text { Other Information } \\
\text { Professionals } \\
\text { Ranking KSA as } \\
\text { Core }\end{array}$ & p-value & Significance \\
\hline Project management & $43 \%$ & $43 \%$ & 0.9126 & NOT significant \\
\hline Change management & $34 \%$ & $37 \%$ & 0.1471 & NOT significant \\
\hline Data-driven decision-making & $32 \%$ & $31 \%$ & 0.5781 & NOT significant \\
\hline Technology & $33 \%$ & $37 \%$ & 0.0476 & Significant \\
\hline $\begin{array}{l}\text { Knowledge of online security } \\
\text { issues }\end{array}$ & $16 \%$ & $11 \%$ & 0.00041 & Significant \\
\hline $\begin{array}{l}\text { Usability testing for } \\
\text { improvement }\end{array}$ & $15 \%$ & $22 \%$ & 0.00002 & Significant \\
\hline Troubleshooting hardware & $13 \%$ & $22 \%$ & 0 & Significant \\
\hline $\begin{array}{l}\text { Social networking application in } \\
\text { information settings }\end{array}$ & $2 \%$ & $5 \%$ & 0.0095 & Significant \\
\hline Managing network systems & $24 \%$ & $27 \%$ & 0.0776 & NOT significant \\
\hline Troubleshooting software & $9 \%$ & $5 \%$ & 1.622 & NOT significant \\
\hline Website design & & & 0.4103 & NOT significant \\
\hline Coding/programming & & & & \\
\hline
\end{tabular}

\section{Discussion}

Participants in this survey identified $10 \mathrm{KSAs}$ as core to academic librarianship. Seven of the 10 core KSAs are what might be considered "soft" or personal skills. Specifically, these seven KSAs include interpersonal communication, writing, teamwork, customer service skills, cultural competence, interacting with diverse communities, and reflective practice grounded in diversity and inclusion. The three remaining KSAs-knowledge of professional ethics, evaluating and selecting resources, and search skills-are more firmly rooted in the domain knowledge of the field of librarianship. Broadly speaking, those KSAs seem to align with previous research and reports on core competencies and critical areas.

For example, several previous studies have identified soft skills as among the most important for librarians and as the top priorities of hiring managers when reviewing applicants. ${ }^{34}$ Further, these soft skills underpin many of the other domain-specific skills and knowledge areas that, while not identified as core, still ranked as very important for academic librarians. For instance, interpersonal communication, customer service skills, cultural competence, and the ability to interact with diverse communities are all necessary to providing front-line, public-facing user services jobs such as reference and instruction. Many of these skills also align with student learning outcome areas defined in ALA's Standards for Accreditation. For example, cultural competence and interacting with diverse communities directly align with ALA standard I.2.6, which states that all graduates of ALA-accredited master's programs should understand "The role of library and information services in a diverse global society, including the role of serving the needs of underserved groups. ${ }^{\prime \prime 3}$ Nevertheless, it is interesting 
that three-quarters of the core skills of academic librarians are essentially generic soft skills. As discussed in more detail below, these results raise questions about education and training for a specialization in academic libraries, as well as questions about the extent to which certain soft skills, such as interpersonal skills, can be taught and assessed.

Three of the 10 core skills are more solidly situated within the specific domain of library and information science: knowledge of professional ethics, evaluating and selecting information resources, and search skills. Again, these results seem to align with previous research identifying core skills or areas. For example, even as academic libraries look to diversify their roles and use of space, a review of strategic plans found that collections are still a top priority for academic libraries, appearing as a strategic goal area in 100 percent of those plans. ${ }^{36}$ In addition, the library's role of procuring and making available resources is one of the areas most highly valued by faculty, especially in the sciences. ${ }^{37}$ Similarly, reference positions, often with instruction responsibilities, continue to remain steady in academic libraries, ${ }^{38}$ and previous studies have confirmed the importance of search skills to reference positions. ${ }^{39}$ As noted above, information literacy and instruction are currently considered one of the most important areas for academic librarians. Librarians in these positions indicate that teaching users to locate and access information is one of their primary areas of responsibility, as well as an area on which they spend much of their instruction time. ${ }^{40}$ Thus, it makes sense that selection and evaluation of resources and search skills would be considered core areas.

While the 10 skills identified as core KSAs are perhaps not surprising in and of themselves, one striking aspect of the results is that not a single technology skill was identified as core by at least 50 percent of respondents. In fact, the top-ranked technology skill, knowledge of online security, was only ranked as core by one-third of respondents, followed by troubleshooting hardware at just under 25 percent. All other technology skills were identified as core by fewer than one-quarter of respondents. This lack of attention to technology skills might seem surprising at first, given the impact of technology on the field and the fact that nearly every aspect of librarians' jobs involve interaction with, understanding of, and instruction in various technologies. However, even these findings seem to align with previous research. For instance, in a series of focus groups on library competencies, researchers in Australia noted "participants observed that library 2.0 should not be tied to specific technological tools (e.g., blogs or wiki), as this may impede scope for libraries and their services to continue to evolve. The focus needs to be on change and how to meet the changing needs of users." ${ }^{41}$ Likewise, Saunders found that, though hiring managers in United States focus groups often mentioned technology as a necessary skill, there was little agreement about which technologies, specifically, were in demand. ${ }^{42}$ Participants in both studies seemed to agree that, when discussing librarianship broadly rather than specific technology skills, emerging professionals had to achieve a certain level of comfort with technology generally, which included learning how to learn and being willing to continuously upgrade their skills. Specific software and hardware or other technical knowledge would be dependent on the setting and position. The results of this study suggest a similar pattern. It is worth noting, too, that this survey was asking respondents to identify skills that are core, or necessary for all emerging professionals regardless of role or job function. This survey suggests that technology skills are not unimportant, but they are more likely to vary by position and over time. Thus, academic librarians generally need to have strong technology skills and a general facility with technology and willingness to learn, but the specific programs, skills, and technologies will depend on the specific job. 
In a similar way, the fact that KSAs associated with trend areas, such as data management, evaluation research, or design thinking, were not identified as core skills does not necessarily mean that they are unimportant. As noted above, many of the skills not ranked as core were still rated as highly important. For example, while only 16 percent of academic library respondents rated data research management as core, an additional 66 percent said it is very important or important. Likewise, only one-third of respondents said that the ability to carry out evaluation research is core, but another 60 percent ranked it as very important or important. There are two possible implications of these findings. The first is that not every emerging academic librarian needs to be grounded in these particular KSAs, but many librarians will need to be familiar with them. As with technology, the suggestion is that the extent of knowledge or ability necessary is more dependent on job function.

Another possibility is that some of these areas are still emerging themselves. For example, many academic libraries are only beginning to offer data management services to their faculty, and others are still exploring the possibility but have not implemented such a service. Thus, some of these trending areas might still be too new to be considered core. Over time, however, they might begin to take on a more central role within academic libraries. Further, some of these emerging areas entail traditional skills as well. Data research management, for instance, can include acquiring, organizing, and providing access to data sets, as well as offering instruction in the location, evaluation, and use of these sets. Thus, data research management incorporates KSAs such as evaluating and selecting information sources, describing information resources, search skills, and providing instruction, some of which have been identified as core.

Finally, it is worth noting that there were a number of statistically significant differences between academic librarians and other information professionals across the KSAs, both core and not. These findings suggest that there are some fundamental differences in terms of the skills and qualifications for information professionals preparing to work in academic libraries compared to other settings. In all cases but one, academic librarians identified the KSA in question as core in lower proportions than the broader group. The only exception to this finding was for usability testing for improvement, where 16 percent of academic librarians ranked the skill as core, compared to 11 percent of the broader population. This suggests that some skills, such as describing information sources, metadata creation and management, and knowledge management are more likely to be considered core skills in settings other than academic libraries.

\section{Conclusions}

The findings of this study suggest a number of implications both for current and emerging academic library professionals as well as for LIS faculty in charge of program curriculum. Perhaps one of the most striking aspects of the study results is that, of the top 10 skills considered to be core by academic librarians, all but three are what might be considered "soft" or personal skills. Areas like writing, interpersonal skills, and teamwork, while certainly important, are not specific to the field of librarianship or to the domain knowledge that defines the field. As noted above, these findings beg the question, raised in other studies with similar findings, of whether and how LIS programs can teach soft skills, as well as how employers balance soft skills against domain-specific knowledge and abilities when hiring. As Saunders speculated in earlier research, the importance of soft skills to library employers signals a need for LIS faculty to directly teach and assess those skills in the classroom. ${ }^{43}$ 
One might imagine that writing skills are incorporated across any graduate curriculum, including LIS, but to what extent are interpersonal, customer service, cultural competence, or reflective practice taught and assessed? The findings of this study suggest that LIS faculty need to find clear and specific ways to integrate these topics directly into the curriculum to ensure that emerging professionals are adequately prepared in these areas. Certainly, these KSAs can likely be integrated into existing courses in many cases. It seems likely that many user services-oriented courses, like reference and instruction, probably incorporate attention to customer service and interpersonal skills. For instance, instructors likely discuss the importance of active listening, open-ended questioning, approachability, interest, and reservation of judgment as part of the reference interview process. Courses on user instruction might integrate content on reflective teaching practice. Group assignments could be a way to introduce and foster teamwork. As noted in the literature review, Jaeger et al. discuss how LIS faculty can integrate more attention to issues of diversity and inclusion in their courses. ${ }^{44}$

An additional question, however, is whether these topics are merely addressed through lectures and readings or whether students are engaged in hands-on practice and are assessed on performance in these areas. For these KSAs to be fully addressed as learning outcomes of an MSLIS program, faculty should provide direct instruction and opportunities for students to demonstrate and be assessed on their abilities. For example, students in a reference course might engage in a practice reference interview in which they would be assessed not just on their ability to correctly and completely answer the question posed but also on their adherence to behavioral aspects of the interview such as active listening and approachability. Likewise, instructors cannot necessarily assume that simply assigning group projects will result in an understanding of and ability to work in teams. Rather, instructors should provide direct instruction on team building, including assessing strengths and assigning roles. Team members might reflect on their own and their teammates' performance throughout the assignment as well as providing a summative assessment at the end. LIS students and emerging professionals will want to consider how to build and showcase experience in these areas. This might mean choosing courses that integrate attention to soft skills as well as highlighting relevant transferable skills from other work experience or extracurricular activities.

This study also compared the relative importance of various KSAs in academic libraries to the broader professions. The results showed that in a number of cases there are significant differences between skills expected of academic librarians compared to the broader information professions, which might initially suggest particular career preparation for academic librarians. At the same time, however, the findings revealed that, while there are a number of KSAs that academic librarians consider to be very important or important, there are only a very few domain-specific skills that they consider to be core for all academic librarians. Rather, the results seem to suggest that the specific skills and knowledge necessary might have more to do with one's role or job function within an academic library setting, rather than being dependent on the setting itself.

Once again, these findings have particular implications for the professional preparation of academic librarians and for LIS faculty designing library curricula. It is not uncommon for MSLIS programs to offer formal or informal paths to specialization within the degree program. For example, Simmons University School of Library and Information Science outlines recommended courses for students interested in user services, youth services, organization of information, and management and leadership. Similarly, Syracuse's iSchool offers specializa- 
tions in areas such as instructional librarianship, data librarianship, and management. Within its program of library and information studies, the University of Rhode Island offers tracks in organization of digital media and libraries, leadership, and transforming communities.

Such tracks and specializations can be very helpful to students, especially in programs with few required courses and many electives. Tracks and specializations help students focus their programs and select courses that will provide them with the depth they need to pursue specific career paths within the information professions. However, given the limited scope of domain-knowledge ranked as core for academic librarians, this study suggests that, when organizing curricula and choosing courses, MSLIS instructors and their students might do better to focus on job roles and functions rather than on the academic library setting as an area of specialization. In other words, while LIS students might well be interested in working in an academic library, they might need to consider what types of positions they hope to gain within that setting and plan their courses and programs around those job functions. In other words, a student interested in user services might take courses focused on information literacy, library instruction, reference, and collection development, while a student interested in data sciences might take courses on data management, information visualization, and statistics. Likewise, iSchools might continue to organize advising and tracks around these functions rather than on information settings. 


\section{Appendix A: KSA Survey}

Q1 The purpose of this survey is to identify foundational skills and knowledge areas for LIS professionals. Please rate the importance of the skills and content areas along the following scale

\section{General Skills and Content Areas}

\begin{tabular}{|c|c|c|c|c|c|}
\hline & $\begin{array}{l}\text { Core (ALL } \\
\text { MSLIS } \\
\text { graduates } \\
\text { should have } \\
\text { a strong } \\
\text { foundation } \\
\text { regardless } \\
\text { of area of } \\
\text { concentration/ } \\
\text { career path) (1) }\end{array}$ & $\begin{array}{l}\text { Very } \\
\text { Important } \\
\text { (most } \\
\text { professionals } \\
\text { will need } \\
\text { to know/be } \\
\text { able to do } \\
\text { this) (2) }\end{array}$ & $\begin{array}{l}\text { Important } \\
\text { (many } \\
\text { professionals } \\
\text { will need to } \\
\text { be familiar } \\
\text { with this } \\
\text { skill/content) } \\
\text { (3) }\end{array}$ & $\begin{array}{l}\text { Specialized } \\
\text { (only } \\
\text { professionals } \\
\text { in specialized } \\
\text { positions are } \\
\text { likely to need } \\
\text { this skill/ } \\
\text { knowledge) } \\
\text { (4) }\end{array}$ & $\begin{array}{l}\text { Not } \\
\text { Important } \\
\text { (5) }\end{array}$ \\
\hline \multicolumn{6}{|l|}{$\begin{array}{l}\text { Evaluating and selecting } \\
\text { information resources ( } 1 \text { ) }\end{array}$} \\
\hline \multicolumn{6}{|l|}{$\begin{array}{l}\text { Describing information } \\
\text { resources ( } 2 \text { ) }\end{array}$} \\
\hline \multicolumn{6}{|l|}{$\begin{array}{l}\text { Taxonomy/classification } \\
\text { development (3) }\end{array}$} \\
\hline \multicolumn{6}{|l|}{$\begin{array}{l}\text { Knowledge management } \\
\text { (4) }\end{array}$} \\
\hline \multicolumn{6}{|l|}{$\begin{array}{l}\text { Research data } \\
\text { management (collecting, } \\
\text { organizing, and making } \\
\text { data accessible) (5) }\end{array}$} \\
\hline \multicolumn{6}{|l|}{$\begin{array}{l}\text { Evaluation research } \\
\text { (collecting and analyzing } \\
\text { data for purposes of } \\
\text { improvement) (6) }\end{array}$} \\
\hline \multicolumn{6}{|l|}{$\begin{array}{l}\text { Management of archival } \\
\text { records and manuscripts } \\
\text { (7) }\end{array}$} \\
\hline \multicolumn{6}{|l|}{$\begin{array}{l}\text { Basic data collection } \\
\text { methods (surveys, focus } \\
\text { groups, etc) (8) }\end{array}$} \\
\hline \multicolumn{6}{|l|}{$\begin{array}{l}\text { Reflective practice } \\
\text { grounded in diversity \& } \\
\text { inclusion (9) }\end{array}$} \\
\hline \multicolumn{6}{|l|}{$\begin{array}{l}\text { Knowledge of } \\
\text { professional ethics (10) }\end{array}$} \\
\hline \multicolumn{6}{|l|}{ Metadata creation (11) } \\
\hline $\begin{array}{l}\text { Metadata management } \\
\text { (12) }\end{array}$ & & & & & \\
\hline
\end{tabular}




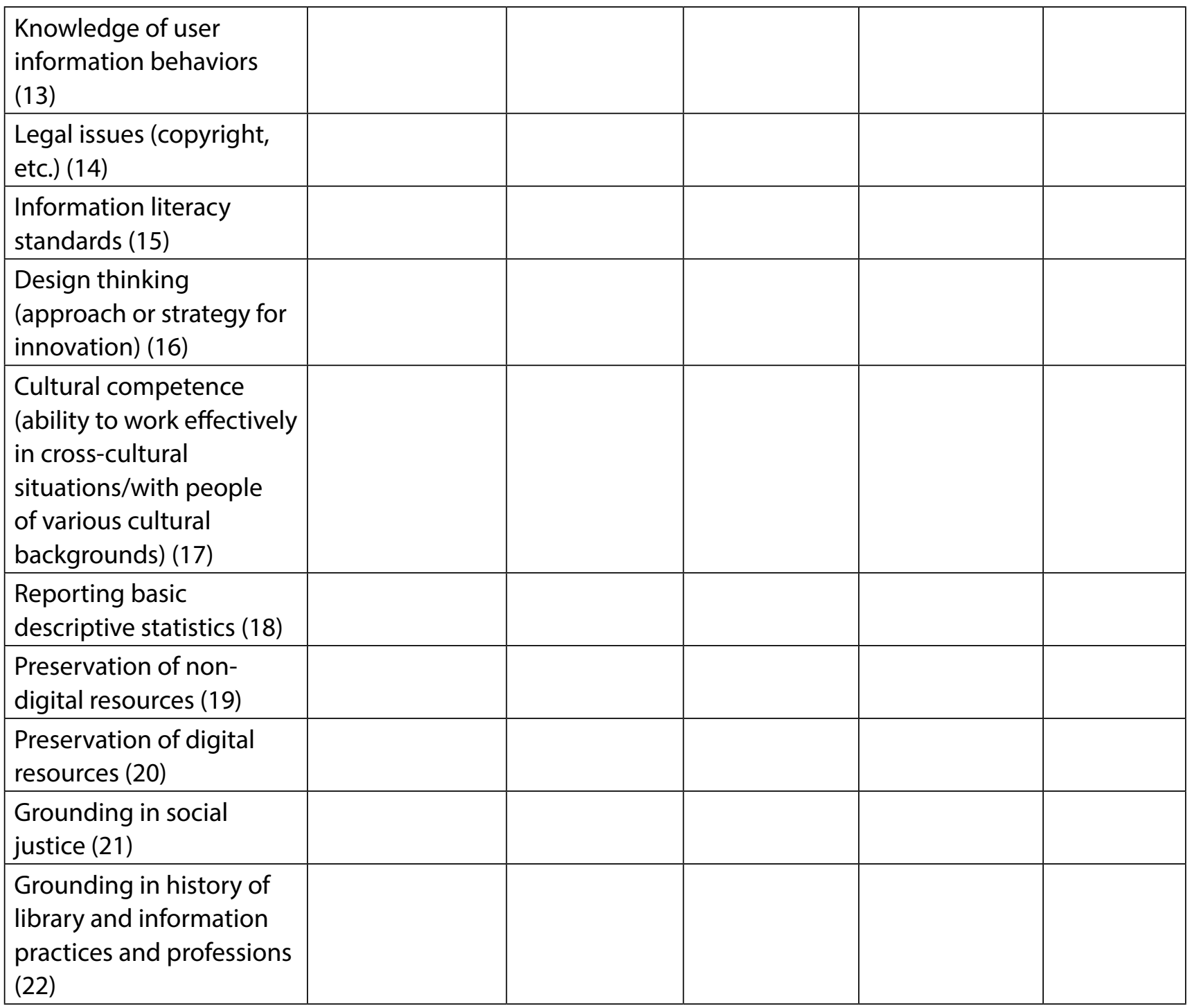

Q2 Communication

\begin{tabular}{|l|l|l|l|l|l|}
\hline & $\begin{array}{l}\text { Core (ALL } \\
\text { MSLIS } \\
\text { graduates } \\
\text { should have } \\
\text { a strong } \\
\text { foundation } \\
\text { regardless } \\
\text { of area of } \\
\text { concentration/ } \\
\text { career path)(1) }\end{array}$ & $\begin{array}{l}\text { Very } \\
\text { Important } \\
\text { (most } \\
\text { professionals } \\
\text { will need to } \\
\text { know/be able } \\
\text { to do this) (2) }\end{array}$ & $\begin{array}{l}\text { Important } \\
\text { (many } \\
\text { professionals } \\
\text { will need to } \\
\text { be familiar } \\
\text { with this } \\
\text { skill/ } \\
\text { content) (3) }\end{array}$ & $\begin{array}{l}\text { Specialized } \\
\text { (only } \\
\text { professionals } \\
\text { in specialized } \\
\text { positions are } \\
\text { likely to need } \\
\text { this skill/ } \\
\text { knowledge) } \\
\text { (4) }\end{array}$ & $\begin{array}{l}\text { Not } \\
\text { Important } \\
\text { (5) }\end{array}$ \\
\hline Writing (1) & & & & & \\
\hline $\begin{array}{l}\text { Interpersonal } \\
\text { communication (2) }\end{array}$ & & & & & \\
\hline Customer service skills (3) & & & & & \\
\hline Public speaking (4) & & & & & \\
\hline
\end{tabular}




\begin{tabular}{|l|l|l|l|l|l|}
\hline $\begin{array}{l}\text { Advocacy (representing } \\
\text { organizational interests } \\
\text { to stakeholders) (5) }\end{array}$ & & & & & \\
\hline Marketing/outreach (6) & & & & & \\
\hline $\begin{array}{l}\text { Making effective visual } \\
\text { presentations (7) }\end{array}$ & & & & & \\
\hline
\end{tabular}

Q4 User Services

\begin{tabular}{|l|l|l|l|l|l|}
\hline & $\begin{array}{l}\text { Core (ALL } \\
\text { MSLIS } \\
\text { graduates } \\
\text { should have } \\
\text { a strong } \\
\text { foundation } \\
\text { regardless } \\
\text { of area of } \\
\text { concentration/ } \\
\text { career path) (1) }\end{array}$ & $\begin{array}{l}\text { Very } \\
\text { Important } \\
\text { (most } \\
\text { professionals } \\
\text { will need } \\
\text { to know/be } \\
\text { able to do } \\
\text { this) (2) }\end{array}$ & $\begin{array}{l}\text { Important } \\
\text { (many } \\
\text { professionals } \\
\text { will need to } \\
\text { be familiar } \\
\text { with this } \\
\text { skill/content) } \\
\text { (3) }\end{array}$ & $\begin{array}{l}\text { Specialized } \\
\text { (only } \\
\text { professionals } \\
\text { in specialized } \\
\text { positions are } \\
\text { likely to need } \\
\text { this skill/ } \\
\text { knowledge) } \\
\text { (4) }\end{array}$ & $\begin{array}{l}\text { Not } \\
\text { Important } \\
\text { (5) }\end{array}$ \\
\hline $\begin{array}{l}\text { Instruction/teaching } \\
\text { (face to face and online) } \\
\text { (1) }\end{array}$ & & & & & \\
\hline $\begin{array}{l}\text { Reference interview/ } \\
\text { question negotiation (2) }\end{array}$ & & & & & \\
\hline $\begin{array}{l}\text { Interacting with diverse } \\
\text { communities (3) }\end{array}$ & & & & & \\
\hline Reader's advisory (4) & & & & & \\
\hline $\begin{array}{l}\text { Search skills (ability } \\
\text { to search databases, } \\
\text { internet resources, and } \\
\text { catalogs efficiently and } \\
\text { effectively) (5) }\end{array}$ & & & & & \\
\hline $\begin{array}{l}\text { Community/user needs } \\
\text { assessment (6) }\end{array}$ & & & & \\
\hline
\end{tabular}

Q5 Management

\begin{tabular}{|l|l|l|l|l|l|}
\hline & $\begin{array}{l}\text { Core (ALL MSLIS } \\
\text { graduates } \\
\text { should have } \\
\text { a strong } \\
\text { foundation } \\
\text { regardless } \\
\text { of area of } \\
\text { concentration/ } \\
\text { career path) (1) }\end{array}$ & $\begin{array}{l}\text { Very } \\
\text { Important } \\
\text { (most } \\
\text { professionals } \\
\text { will need } \\
\text { to know/be } \\
\text { able to do } \\
\text { this) (2) }\end{array}$ & $\begin{array}{l}\text { Important } \\
\text { (many } \\
\text { professionals } \\
\text { will need to } \\
\text { be familiar } \\
\text { with this } \\
\text { skill/content) } \\
\text { (3) }\end{array}$ & $\begin{array}{l}\text { Specialized } \\
\text { (only } \\
\text { professionals } \\
\text { in specialized } \\
\text { positions are } \\
\text { likely to need } \\
\text { this skill/ } \\
\text { knowledge) } \\
\text { (4) }\end{array}$ & $\begin{array}{l}\text { Not } \\
\text { Important } \\
\text { (5) }\end{array}$ \\
& & & & & \\
\hline $\begin{array}{l}\text { Fundamentals of } \\
\text { management (1) }\end{array}$ & & & & & \\
\hline
\end{tabular}




\begin{tabular}{|l|l|l|l|l|l|}
\hline Project management (2) & & & & & \\
\hline Budgeting (3) & & & & & \\
\hline Grant writing (4) & & & & & \\
\hline $\begin{array}{l}\text { HR/personnel } \\
\text { management (5) }\end{array}$ & & & & \\
\hline $\begin{array}{l}\text { Facilities management } \\
(6)\end{array}$ & & & & \\
\hline $\begin{array}{l}\text { Data-driven decision- } \\
\text { making (7) }\end{array}$ & & & & & \\
\hline Leadership (8) & & & & \\
\hline $\begin{array}{l}\text { Change management } \\
\text { (9) }\end{array}$ & & & & & \\
\hline Teamwork (10) & & & & \\
\hline
\end{tabular}

Q6 Technology

\begin{tabular}{|l|l|l|l|l|l|}
\hline & $\begin{array}{l}\text { Core (ALL MSLIS } \\
\text { graduates } \\
\text { should have } \\
\text { a strong } \\
\text { foundation } \\
\text { regardless } \\
\text { of area of } \\
\text { concentration/ } \\
\text { career path) (1) }\end{array}$ & $\begin{array}{l}\text { Very } \\
\text { Important } \\
\text { (most } \\
\text { professionals } \\
\text { will need } \\
\text { to know/be } \\
\text { able to do } \\
\text { this) (2) }\end{array}$ & $\begin{array}{l}\text { Important } \\
\text { (many } \\
\text { professionals } \\
\text { will need to } \\
\text { be familiar } \\
\text { with this } \\
\text { skill/content) } \\
\text { (3) }\end{array}$ & $\begin{array}{l}\text { Specialized } \\
\text { (only } \\
\text { professionals } \\
\text { in specialized } \\
\text { positions are } \\
\text { likely to need } \\
\text { this skill/ } \\
\text { knowledge) } \\
\text { (4) }\end{array}$ & $\begin{array}{l}\text { Not } \\
\text { Important } \\
\text { (5) }\end{array}$ \\
\hline $\begin{array}{l}\text { Coding/programming } \\
\text { (1) }\end{array}$ & & & & & \\
\hline $\begin{array}{l}\text { Troubleshooting } \\
\text { software (2) }\end{array}$ & & & & & \\
\hline $\begin{array}{l}\text { Troubleshooting } \\
\text { hardware (3) }\end{array}$ & & & & & \\
\hline $\begin{array}{l}\text { Knowledge of online } \\
\text { security issues (4) }\end{array}$ & & & & & \\
\hline Web site design (5) & & & & & \\
\hline $\begin{array}{l}\text { Social networking } \\
\text { application in } \\
\text { information settings (6) }\end{array}$ & & & & & \\
\hline $\begin{array}{l}\text { Usability testing for } \\
\text { improvement (7) }\end{array}$ & & & & \\
\hline $\begin{array}{l}\text { Managing network } \\
\text { systems (8) }\end{array}$ & & & & \\
\hline
\end{tabular}


Q7 Are there any additional skills or content areas that you believe should be covered in the MSLIS curriculum?

Q8 Do you have an MSLIS degree

1. Yes (1)

2. No (2)

Q9 Which of the following best describes your current position?

1. Director/Dean/Head (1)

2. Department Manager (2)

3. Staff Librarian (3)

4. Staff Archivist (4)

5. Library/archival Assistant (5)

6. LIS Faculty (6)

7. Adjunct Faculty (7)

8. Other (8)

Q10 Which of the following best describes your place of employment?

1. Public Library (1)

2. Academic Library (2)

3. Corporate Library (3)

4. School Library (4)

5. Special Library (5)

6. Academic Archive (6)

7. Community Archive (7)

8. Museum (8)

9. Government Archive (9)

10. Technology Provider or Vendor (10)

11. Other (11)

Q11 Please tell us which organization invited you to take this survey?

1. A

2. B

3. C

4. D

\section{Notes}

1. "ALA's Core Competences of Librarianship," American Library Association (last modified Jan. 27, 2009), available online at www.ala.org/educationcareers/sites/ala.org.educationcareers/files/content/careers/corecomp/ corecompetences/finalcorecompstat09.pdf [accessed 16 January 2020].

2. "Standards for Accreditation of Master's Programs in Libraries and Information Studies," American Library Association (last modified Feb. 2, 2015), available online at www.ala.org/educationcareers/sites/ala.org. educationcareers/files/content/standards/Standards_2015_adopted_02-02-15.pdf [accessed 16 January 2020].

3. "ACRL Proficiencies for Assessment Librarians and Coordinators," Association of College \& Research Libraries (last modified Jan. 2017), available online at www.ala.org/acrl/standards/assessment_proficiencies [accessed 16 January 2020]. 
4. "Roles and Strengths of Teaching Librarians," Association of College \& Research Libraries (last modified Apr. 28, 2017), available online at www.ala.org/acrl/standards/teachinglibrarians [accessed 16 January 2020].

5. "Diversity Standards: Cultural Competency for Academic Librarians," Association of College \& Research Libraries (last modified 2012), available online at www.ala.org/acrl/standards/diversity [accessed 16 January 2020].

6. "Standards for Distance Learning Library Services," Association of College \& Research Libraries (last modified June 2016), available online at www.ala.org/acrl/standards/guidelinesdistancelearning [accessed 16 January 2020].

7. ACRL Research Planning and Review Committee, “2016 Top Trends in Academic Libraries," College $\mathcal{E}$ Research Libraries 77, no. 6 (2016), available online at https://crln.acrl.org/index.php/crlnews/article/view/9505/10798 [accessed 26 October 2018]; ACRL Research Planning and Review Committee, "2018 Top Trends in Academic Libraries," College \& Research Libraries 79, no. 6 (2018), available online at https://crln.acrl.org/index.php/crlnews/ article/view/17001/18750 [accessed 26 October 2018].

8. Lisa Federer, "Defining Data Librarianship: A Survey of Competencies, Skills, and Training," Journal of the Medical Library Association 106, no. 3 (2018), dx.doi.org/10.5195/jmla.2018.306.

9. Jingfeng Xia and Minglu Wang, "Competencies and Responsibilities of Social Science Data Librarians: An Analysis of Job Descriptions," College \& Research Libraries 75, no. 3 (2014), available online at https://crl.acrl. org/index.php/crl/article/view/16367 [accessed 27 October 2018].

10. Hsin-liang Chen and Yin Zhang, "Educating Data Management Professionals: A Content Analysis of Job Descriptions," Journal of Academic Librarianship 43, no. 1 (2017): 18-24, https://doi.org/10.1016/j.acalib.2016.11.002.

11. ACRL Research Planning and Review Committee, "2018 Top Trends in Academic Libraries."

12. ACRL Research Planning and Review Committee, "2016 Top Trends in Academic Libraries."

13. "Framework for Information Literacy for Higher Education," Association of College and Research Libraries (last updated Jan. 11, 2016), available online at www.ala.org/acrl/standards/ilframework [accessed 16 January 2020].

14. Deanna Marcum and Roger C. Schonfeld, "Universities Are Changing and So Are Their Libraries," Ithaka $S+R$ (last updated Oct. 18, 2018), available online at https://sr.ithaka.org/blog/universities-are-changing-and-soare-their-libraries/ [accessed 16 January 2020].

15. Christine Wolf, "Ithaka S+R US Library Report," Ithaka S+R (Apr. 3, 2017), available online at https:// sr.ithaka.org/wp-content/uploads/2017/03/SR_Report_Library_Survey_2016_04032017.pdf [accessed 16 January 2020].

16. Hanrong Wang, Yingqi Tang, and Carley Knight, "Contemporary Development of Academic Reference Librarianship in the United States: A 44-year Content Analysis," Journal of Academic Librarianship 36, no. 6 (2010): 484-94.

17. Robert Detmering and Claudene Sproles, "Forget the Desk Job: Current Roles and Responsibilities in Entry-Level Reference Job Advertisements," College \& Research Libraries 73, no. 6 (2012), available online at https:// crl.acrl.org/index.php/crl/article/view/16265 [accessed 16 January 2020].

18. Russell A. Hall, "Beyond the Job Ad: Employers and Library Instruction," College \& Research Libraries 74, no. 1 (2014) (retrieved Oct. 27, 2018), available online at https://crl.acrl.org/index.php/crl/article/view/16276/0 [accessed 16 January 2020].

19. Kristen Radsliff Rebmann, Simone Molitor, and Bonnie Rainey, “Distance Learning Skills and Responsibilities: A Content Analysis of Job Announcements 1996-2010," Journal of Library E Information Services in Distance Learning 6, no. 2 (2012): 100-16; Yingqi Tang, "Distance Education Librarians in the United States: A Study of Job Announcements," Journal of Academic Librarianship 39, no. 6 (2013): 500-05, https://doi.org/10.1016/j. acalib.2013.08.012.

20. Janie M. Mathews and Harold Pardue, "The Presence of IT Skill Sets in Librarian Position Announcements," College E Research Libraries 70, no. 3 (2009): 255, available online at https:/crl.acrl.org/index.php/crl/article/ view/16009/17455 [accessed 27 October 2018].

21. Jaya Raju, "Information Professional or IT Professional? The Knowledge and Skills Required by Academic Librarians in the Digital Library Environment," portal: Libraries and the Academy 17, no. 4 (2017): 163-70.

22. Helen Partridge, Julie Lee, and Carrie Munro, "Becoming Librarian 2.0: The Skills, Knowledge, and Attributes Required by Library and Information Science Professionals in a Web 2.0 World (and Beyond)," Library Trends 59, no. 1/2 (2010): 315-36.

23. Laura Saunders, "Employer Perspectives on Library and Information Science Education," Library Quarterly 85, no. 4 (2015): 427-53.

24. See, for example, Anne Goulding, Graham Walton, and Derek Stephens, "The Importance of Political and Strategic Skills for UK Library Leaders," Australian Library Journal 61, no. 2 (2012): 105-18; Colleen S. Harris-Keith, 
"What Academic Library Leadership Lacks: Leadership Skills Directors Are Least Likely to Develop, and Which Positions Offer Development Opportunity," Journal of Academic Librarianship 42, no. 4 (2016): 313-18.

25. See, for example, Denice Adkins, Christina Verdin, and Charles Yier, "Learning about Diversity: The Roles of LIS Education, LIS Associations, and Lived Experience," Library Quarterly 85, no. 2 (2015): 139-49; Paul T. Jaeger et al., "The Virtuous Circle Revisited: Injecting Diversity, Inclusion, Rights, Justice, and Equity into LIS from Education to Advocacy," Library Quarterly 85, no. 2 (2015): 150-71.

26. Karen Okamoto and Mark Aaron Polger, "Off to Market We Go," Library Leadership \& Management 26, no. 1 (2012): 1-20.

27. Mark D. Winston and Lisa Dunkley, “Leadership Competencies for Academic Librarians: The Importance of Development and Fundraising," College $\mathcal{E}$ Research Libraries 63, no 2 (2002): 171-82, available online at https:// crl.acrl.org/index.php/crl/article/view/15515/0 [accessed 27 October 2018].

28. See, for example, Dick Kawooya, Amber Veverka, and Thomas Lipinski, "The Copyright Librarian: A Study of Advertising Trends for the Period 2006-2013," Journal of Academic Librarianship 41, no. 3 (2015): 341-49; Deborah H. Charbonneau and Michael Priehs, "Copyright Awareness, Partnerships, and Training in Academic Libraries," Journal of Academic Librarianship 40, no. 3/4 (2014): 228-33.

29. Rachel Applegate, "Educating Assessors: Preparing Librarians with Micro and Macro Skills," EvidenceBased Library and Information Practice 11, no. 2 (2016): 74-86, https://doi.org/10.18438/B89D0P.

30. Sarah Passoneau and Susan Erickson, "Core Competencies for Assessment in Libraries," Library Leadership \& Management, 28, no. 4 (2014): 1-19.

31. Li Zhang, "Foreign Language Skills and Academic Library Job Announcements: A Survey and Trends Analysis 1966-2006," Journal of Academic Librarianship 34, no. 4 (2008): 322-31.

32. Jennifer Ferguson, "Additional Degree Required? Advanced Subject Knowledge and Academic Librarianship," portal: Libraries and the Academy 16, no. 4 (2016): 721-36.

33. See, for example, Partridge, Lee, and Munro, "Becoming Librarian 2.0"; Saunders, "Employer Perspectives on Library and Information Science Education."

34. See, for example, Partridge, Lee, and Munro, “Becoming Librarian 2.0”; Saunders, "Employer Perspectives on Library and Information Science Education."

35. American Library Association, "Standards for Accreditation of Master's Programs in Libraries and Information Studies."

36. Laura Saunders, "Academic Libraries' Strategic Plans: Top Priorities and Under-Recognized Areas," Journal of Academic Librarianship 41, no. 3 (2015): 285-91.

37. Ross Housewright, Roger C. Shonfeld, and Kate Wulfson, "Ithaka S+R US: Faculty Survey 2012," Ithaka S+R, available online at https://sr.ithaka.org/wp-content/uploads/2015/08/Ithaka_SR_US_Faculty_Survey_2012_FINAL. pdf [accessed 3 November 2018].

38. Wang, Tang, and Knight, "Contemporary Development of Academic Reference Librarianship in the United States."

39. Laura Saunders, "Identifying Core Reference Competencies from an Employers' Perspective: Implications for Instruction," College \& Research Libraries 73, no. 4 (2012): 390-404, available online at https://crl.acrl.org/index.

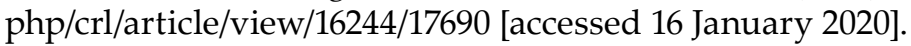

40. Heidi Julien, Melissa Gross, and Don Latham, "Survey of Information Literacy Instructional Practices in U.S. Academic Libraries," College \& Research Libraries 79, no. 2 (2018): 179-99, available online at https://crl.acrl. org/index.php/crl/article/view/16606 [accessed 16 January 2020].

41. Helen Partridge et al., "The Contemporary Librarian: Skills, Knowledge and Attributes Required in a World of Emerging Technologies," Library and Information Science Research in Australia 32, no. 4 (2010): 271.

42. Saunders, "Employer Perspectives on Library and Information Science Education."

43. Saunders, "Employer Perspectives on Library and Information Science Education."

44. Jaeger et al., "The Virtuous Circle Revisited." 